\title{
COMMUNICATIONS
}

\section{OCULAR COMPLICATIONS IN SICKLE-CELL HAEMOGLOBIN C DISEASE*}

\author{
BY \\ STEWART MUNRO AND COLIN WALKER \\ London
}

THE increase in the coloured population in Great Britain during the past 10 years has given an opportunity of observing a disease which has hitherto been reported mainly in the American literature and in papers submitted by clinicians in West Africa.

According to the Home Office, there are approximately 115,000 West Indians and 25,000 West Africans in the United Kingdom. In 1950-53 the net inward movement of West Indians was only 2,000 to 3,000 per year; by 1956 this had risen to 30,000 per year, though there has since been a slight decline.

Sickle-cell haemoglobin $\mathrm{C}$ disease, which is found exclusively in the Negro race, is characterized by recurrent infarctive episodes, sometimes mild and asymptomatic but occasionally severe and fatal in their outcome. The eye suffers recurrent intra-ocular haemorrhages, and other organs and tissues (notably the spleen, kidney, and bones) are affected by this infarction through the mechanical obstruction of the small capillaries by inflexible red cells. Goodman, von Sallmann, and Holland (1957) reported the disease to be present in 10,000 to 20,000 American Negroes. Hook and Cooper (1958) put the incidence at 1 in 1,500 American Negroes. Raper (1950) found that, of an estimated population of 200,000,000 Negroes in Africa south of the Sahara, 40 million carried the sickle-cell trait.

About 22 cases with ocular complications in sickle-cell haemoglobin $\mathrm{C}$ disease have so far been described in the literature. It is the purpose of this paper to describe a further nine cases. A comparison with those previously reported suggests that there is a specific retinopathy which may be present without any symptoms of visual disturbance.

There is still a certain amount of confusion concerning the homozygous sickle-cell anaemia and its heterozygous genetic variants. This mainly occurs when cases are reported without electrophoretic separation of the various abnormal haemoglobins.

It may therefore be of interest to trace the progress which has been made in the classification of the variants of sickle-cell anaemia, which are now regarded as disorders with their own peculiar clinical features.

Although the first clinical case of sickle-cell anaemia was reported by Herrick (1910), who described "peculiar elongated sickle-shaped red corpuscles in a case of severe anaemia", it was not known until 1949 that sickle- 
cell haemoglobin and normal haemoglobin presented a characteristic difference in electrophoretic motility (Pauling, Itano, Singer, and Wells, 1949). This important discovery that the abnormality in the sickled red cell was due to the type of haemoglobin led to further investigations, which revealed additional abnormal haemoglobins. When, as a result of inheritance, these are associated with the abnormal haemoglobin responsible for sickling, they give rise to genetic variants now recognized as distinct clinical entities. Only a few years ago patients exhibiting the sickling phenomenon were thought to have either a sickle-cell anaemia or a mild variant form of the disease, relatively benign and not associated with haemolytic or infarctive episodes.

Table I illustrates some of these variants. Where there is a combination of an abnormal haemoglobin with a normal haemoglobin, the condition may be described as a trait, but if both haemoglobins are abnormal the condition may be regarded as a disease. The combination of two similar genes produces a homozygous state and that of two different genes a heterozygous state.

TABLE I

\begin{tabular}{c|l|c|c}
\hline $\begin{array}{c}\text { Haemoglobin } \\
\text { Type }\end{array}$ & \multicolumn{1}{|c|}{ Disease } & \multicolumn{1}{|c|}{ State } & $\begin{array}{c}\text { Prevalence in American } \\
\text { Negroes (after Hook } \\
\text { and Cooper, 1958) }\end{array}$ \\
\hline AS & Sickle-cell trait & Heterozygous & 8 to 11 per cent. \\
\hline SS & Sickle-cell anaemia & Homozygous & $1: 600$ \\
\hline AC & Hb C trait & Heterozygous & 2 to 3 per cent. \\
\hline SC & Sickle-cell Hb C disease & Heterozygous & $1: 1,500$ \\
\hline CC & Homozygous C disease & Homozygous & $1: 6,000$ \\
\hline SD & Sickle-cell Hb D disease & Heterozygous & - \\
\hline $\begin{array}{c}\text { SF } \\
\text { (F Foetal Hb) }\end{array}$ & $\begin{array}{l}\text { Sickle-cell thalassaemia } \\
\text { disease }\end{array}$ & Heterozygous & - \\
\hline
\end{tabular}

These abnormal haemoglobins were discovered by filter paper electrophoresis. If the colloid particles of a protein in solution are placed in an electric field, they move either to the cathode or to the anode depending on the acidity or alkalinity of the solution. At a certain hydrogen ion concentration no movement takes place, and it is at this (iso-electric) point that the protein precipitates. It is the small differences in the iso-electric point of the various human haemoglobins that allow separation by electrophoresis. The laboratory technique requires $4 \mathrm{ml}$. blood collected in an anti-coagulant (e.g. E.D.T.A.) for these estimates to be carried out.

The filter paper (Fig. 1, opposite) shows the varying motility of some of the abnormal haemoglobins, the pattern being achieved by the different rates of migration towards the anode. The abnormal $\mathrm{S}$ and $\mathrm{C}$ pattern was given by blood from Case 4 . 
So many new haemoglobins are now being found that allocation by letters risks confusion, and it is suggested that the name of the place of origin be used provisionally until the final nomenclature is decided by international agreement.

In all the cases with ocular complications which have been reported to date, haemoglobin $\mathrm{S}$ has been present, the sickling phenomenon being confined solely to the red cell with this abnormal haemoglobin. In low-oxygen atmospheres the sickle-cell haemoglobin is reduced, and in this less soluble state the long, thin, rod-like particles of the haemoglobin assume a parallel and equidistant arrangement (Harris, J. W., 1950). These crystals give the red blood cell a sickle-cell shape. This is reversible and upon re-oxygenation the cell will assume a normal contour. The sickle cells, being rigid in the capillaries, impact there instead of altering shape like normal red blood cells, and in addition they may become attached and fail to slide over each other. Stasis and thrombosis with haemorrhage therefore results, causing a further anoxia with endarteritis and infarction. Thromboses are therefore particularly likely to build up around these masses of sickle cells. Bunting (1939) noted that these sickle cells do not show any rouleau formation; the

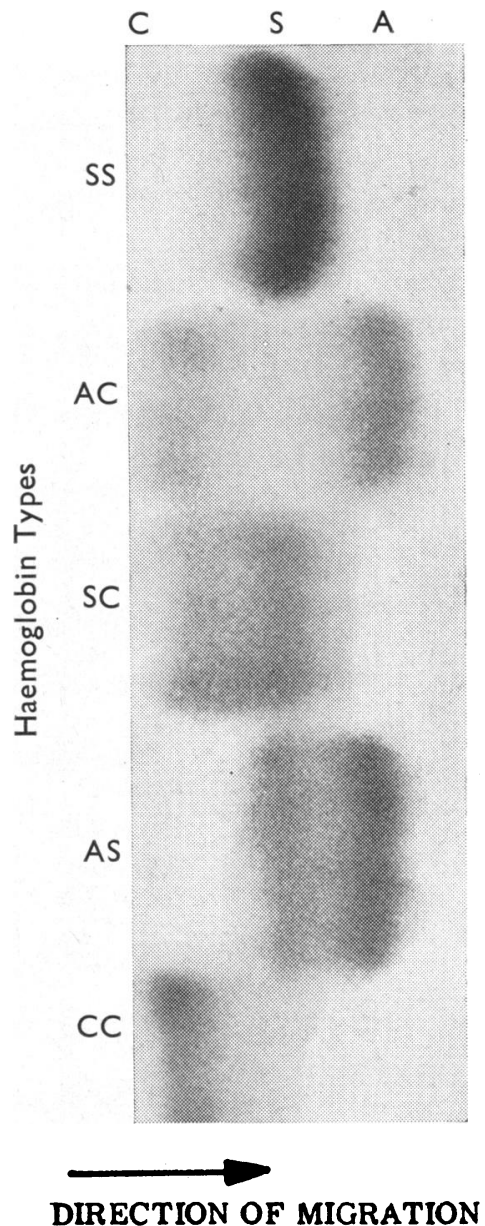

Fig. 1.-Electrophoretic patterns of different types of haemoglobin.

blood sedimentation rate may therefore be normal in severe sickle-cell anaemia. Kimmelstiel (1948) concluded that kidney lesions in cases of sickle-cell anaemia were rarely purely thrombotic but were due to spasm with ischaemia and necrosis, the injury to the vessel wall being caused by the plugging of the capillaries with sickle cells. Chapman, Reeder, Friedman, and Baker (1955), reviewing cases of haematuria occurring in sickle-cell haemoglobin $\mathrm{C}$ disease, considered the kidney to be particularly susceptible to the effects of shock, infarction, and ischaemia, and suggested that these effects might cause local changes in the kidney which were responsible for 
the anoxia precipitating the sickling. No evidence of thrombosis was found in any of the kidney sections. Goodman and others (1957) and Isbey, Clifford, and Tanaka (1958) carried out special coagulation studies, but no disorder of coagulation times was discovered in their series of cases. Walters (1958) urged the necessity of further investigation of the plasma protein constituents in sickle-cell anaemia. These were estimated by Hook and Cooper (1958) in fourteen cases of sickle-cell haemoglobin C disease; there were no abnormal findings, although the total serum protein was elevated in four of 26 cases of sickle-cell anaemia, three of which showed an increase in the globulin fraction. In three other cases the total serum protein was normal but the albumin-globulin ratio was reversed.

The majority of the pathological findings in sickle-cell haemoglobin $\mathrm{C}$ disease are due to widespread infarctions in the small capillaries, and the eye is no exception. It is important to look for signs of retinopathy because

TABLE II HAEMOGLOBIN TYPES IN WHICH

\begin{tabular}{|c|c|c|c|c|c|c|}
\hline \multirow{2}{*}{$\begin{array}{l}\text { Haemo- } \\
\text { globin } \\
\text { Type }\end{array}$} & \multicolumn{4}{|c|}{ Blood Picture } & \multicolumn{2}{|r|}{ Clinical } \\
\hline & Anaemia & Sickling & $\begin{array}{l}\text { Target Cells } \\
\text { (per cent. } \\
\text { Wintrobe) }\end{array}$ & $\begin{array}{c}\text { Red and White } \\
\text { Blood Cells }\end{array}$ & $\begin{array}{l}\text { Respira- } \\
\text { tory } \\
\text { System }\end{array}$ & Abdomen \\
\hline AS & No haemolysis & $\begin{array}{c}\text { In wet pre- } \\
\text { parations } \\
\text { left } 24 \mathrm{hrs} \\
\text { or more }\end{array}$ & 4 & & & \\
\hline SS & $\begin{array}{l}\text { Chronic } \\
\text { haemolytic, } \\
\text { severe and } \\
\text { well marked } \\
\text { Survival rare } \\
\text { beyond } 30 \\
\text { yrs of age }\end{array}$ & At once & 5 to 30 & $\begin{array}{l}\text { May be } 1 \text { to } 2 \\
\text { million } \\
\text { R.B.C.s } \\
\text { /c. } \mathrm{mm} \text {. }\end{array}$ & $\begin{array}{r}\text { Pulmonary } \\
\text { infarction }\end{array}$ & $\begin{array}{l}\text { Severe abdominal } \\
\text { pain in crises } \\
\text { Splenomegaly } \\
\text { not common } \\
\text { Hepatomegaly } \\
\text { present }\end{array}$ \\
\hline SC & $\begin{array}{l}\text { Transient } \\
\text { haemolytic } \\
\text { episodes }\end{array}$ & $\begin{array}{l}\text { In wet sealed } \\
\text { prepara- } \\
\text { tions }\end{array}$ & $\begin{array}{l}20 \text { to } 100 \\
\text { (average } \\
60) \\
\text { (Hannon, } \\
\text { 1956, } \\
\text { Hook and } \\
\text { Cooper, } \\
\text { 1958) }\end{array}$ & \begin{tabular}{|l|} 
Slight \\
anisocytosis \\
Hypochromia \\
Poikilocytosis \\
but not \\
constant \\
Leukocytosis \\
during crises
\end{tabular} & $\begin{array}{l}\text { Pulmonary } \\
\text { infarction }\end{array}$ & $\begin{array}{l}\text { Spleen } \\
\text { progressively } \\
\text { enlarged } \\
\text { Abdominal pain } \\
\text { less common and } \\
\text { less severe }\end{array}$ \\
\hline SF & $\begin{array}{l}\text { Chronic } \\
\text { haemolytic }\end{array}$ & $\begin{array}{l}\text { After latent } \\
\text { period in } \\
\text { vitro }\end{array}$ & 20 to 40 & $\begin{array}{l}\text { Microcytosis } \\
\text { Red cell count } \\
\text { may be high } \\
\text { but packed } \\
\text { cell volume } \\
\text { lower }\end{array}$ & & Splenomegaly \\
\hline
\end{tabular}


these lesions, although symptomless, may be recognizable ophthalmoscopically, whereas lesions in the bone, spleen, lung, or brain may be overlooked unless they cause pain or loss of function. This is of particular importance in sickle-cell haemoglobin $\mathrm{C}$ disease where the anaemia may not be apparent between crises. The blood picture, clinical signs, and ocular complications in the cases reported between 1930 and 1958 are analysed in Table II.

\section{Case Reports}

Case 1, a male West-African Negro from Ghana aged 29 years, was first found to have peripheral retinal changes while being examined for a pair of spectacles on September 16, 1952. His visual acuity could be corrected to $6 / 6$ in each eye and he had no symptoms.

The retinal changes consisted of numerous deep and superficial haemorrhages round the periphery of both fundi, with varicose swellings of the retinal vessels. In one area at 4 o'clock in the left eye there was retinal fibrosis. The diagnosis of Eales's disease was made, and the patient was examined for signs of tuberculosis, but no evidence of this was

OCULAR COMPLICATIONS HAVE BEEN REPORTED

\begin{tabular}{|c|c|c|c|c|}
\hline \multicolumn{4}{|l|}{ Signs } & \multirow[b]{2}{*}{ Ocular Complications } \\
\hline \multirow[t]{2}{*}{ Radiology } & $\begin{array}{l}\text { Central Nervous } \\
\text { System }\end{array}$ & $\begin{array}{l}\text { Cardio- } \\
\text { Vascular } \\
\text { System }\end{array}$ & $\begin{array}{l}\text { Genito-urinary } \\
\text { System }\end{array}$ & \\
\hline & & & $\begin{array}{l}\text { Haematuria } \\
\text { (Chapman, Fried- } \\
\text { man, and Reader, } \\
\text { 1955) }\end{array}$ & $\begin{array}{l}\text { Vitreous haemorrhages } \\
\text { Four cases (Isbey and } \\
\text { others, 1958) } \\
\text { One case (Kennedy } \\
\text { and Cope, 1957) }\end{array}$ \\
\hline $\begin{array}{l}\text { Lesions mainly due to } \\
\text { haemolytic anaemia } \\
\text { in skull, vertebrae, } \\
\text { and tibia } \\
\text { Lesions mainly due to } \\
\text { infarction in hands } \\
\text { and feet }\end{array}$ & $\begin{array}{l}\text { Frequent signs due } \\
\text { to cerebral } \\
\text { infarcts }\end{array}$ & $\begin{array}{c}\text { Systolic } \\
\text { murmur } \\
\text { Dilated } \\
\text { heart }\end{array}$ & $\begin{array}{l}\text { Haematuria } \\
\text { Priapism }\end{array}$ & $\begin{array}{l}\text { Greenish yellow } \\
\text { conjunctivae } \\
\text { Fundi showed } \\
\text { engorged tortuous } \\
\text { veins (Smith and } \\
\text { Conley, 1854; } \\
\text { Harden, 1937; } \\
\text { Wintrobe, 1956; } \\
\text { Hook and Cooper, } \\
\text { 1958) }\end{array}$ \\
\hline \multirow[t]{2}{*}{$\begin{array}{l}\text { Lesions mainly due to } \\
\text { infarction } \\
\text { Aseptic necrosis of } \\
\text { humeral and femoral } \\
\text { heads } \\
\text { Bone infarcts especially } \\
\text { in tibia }\end{array}$} & $\begin{array}{l}\text { Subarachnoid } \\
\text { haemorrhages } \\
\text { Convulsions (Cook, } \\
\text { 1930; Hannon, } \\
\text { 1956; Hook and } \\
\text { Cooper, 1958) }\end{array}$ & & $\begin{array}{l}\text { Frequent haematuria } \\
\text { (Smith and Conley, } \\
\text { 1954; Chapman } \\
\text { and others, 1955) } \\
\text { Decrease in urinary } \\
\text { concentration } \\
\text { ability (Goodman } \\
\text { and others, 1957) }\end{array}$ & $\begin{array}{l}\text { Vitreous haemor- } \\
\text { rhages } \\
\text { Characteristic } \\
\text { peripheral retinal } \\
\text { changes }\end{array}$ \\
\hline & & & & $\begin{array}{l}\text { Rudd, Evans, and } \\
\text { Peeney (1953) } \\
\text { Exudative detachment } \\
\text { of retina } \\
\text { Haemorrhages } \\
\text { (This may have been } \\
\text { a case of SC) }\end{array}$ \\
\hline
\end{tabular}


found and a Wassermann reaction was also negative. The patient then left London, but he returned 6 years later to the same clinic, giving a history of loss of vision in the left eye of 7 weeks' duration. There had been three similar attacks between 1955 and 1957 in the same eye with recovery on each occasion. He had noticed that the attacks always followed an attack of "influenza".

Past History.-Joint pains in arms and legs all his life, until a few years ago. No haematuria. The patient was uncertain whether he had had malaria.

Family History.-Father died aged 69, mother alive and well, no consanguinity. Six married sisters all well with no complications during any of their pregnancies. One nephew reported to have had convulsions.

Ophthalmological Examination (14.8.58)

Right Eye: Visual acuity 6/4. Anterior segment normal. Vitreous clear. Fundus showed widespread peripheral arteriovenous communications with varicose dilations and small pigmented retinal scars not directly associated with the vessels. At 3 o'clock there was a curious "red" area which simulated the appearance of a retinal tear and this was surrounded by marked fibrosis. No sheathing of the vessels was present.

Left Eye: Visual acuity perception of light. Anterior segment normal. Ocular tension normal. Total vitreous haemorrhage obscured fundus details.

General Examination.-No abnormality beyond a palpable spleen.

\section{Laboratory Findings}

Blood: Red cell count and differential white cell count normal, except for a slight eosinophilia.

Blood Film: Red cells showed many target forms. These are red cells with a peculiar aggregation of central pigment. There were no nucleated red cells. Slight anisocytosis, poikilocytosis, 25 per cent. sickling of red cells in anaerobic preparations after $24 \mathrm{hrs}$, and marked sickling in wet sealed preparations after 1 hour.

Serum Electrophoresis: Abnormal haemoglobins S and C.

Serum Bilirubin: $1.25 \mathrm{mg}$. per cent.

Blood Wassermann Reaction: Negative.

Filarial Complement-Fixation Test: Negative.

Urine: Marked excess of urinobilinogen.

Stools: Hookworm ova.

$X$-rays: Skull, chest, shoulders, hips, and tibia normal.

Treatment.-Diamox $500 \mathrm{mg}$. daily to reduce dissociation of oxyhaemoglobin.

Progress.-When the patient was last examined (10.2.59) the visual acuity was $6 / 5$ with glasses in the right eye, and 6/12 with glasses in the left. Fig. $2(a, b$, opposite) shows the fundus appearances at the last examination. The "red" area is shown in Fig. $2(a)$.

Case 2, a male West-African Negro from Ghana aged 24 years, was admitted to hospital after a light blow to the right eye which seemed to cause loss of vision. The visual acuity had previously been recorded at a medical examination as $6 / 6$ in each eye, with a correction for low myopia.

Past History.-Recurrent pains in arms and legs since childhood had ceased to trouble him in 1950. There had been pain in the left hypochondrium with fever in 1958 . He had never been known to be anaemic or jaundiced and had no history of haematuria. He had had several attacks of malaria. 


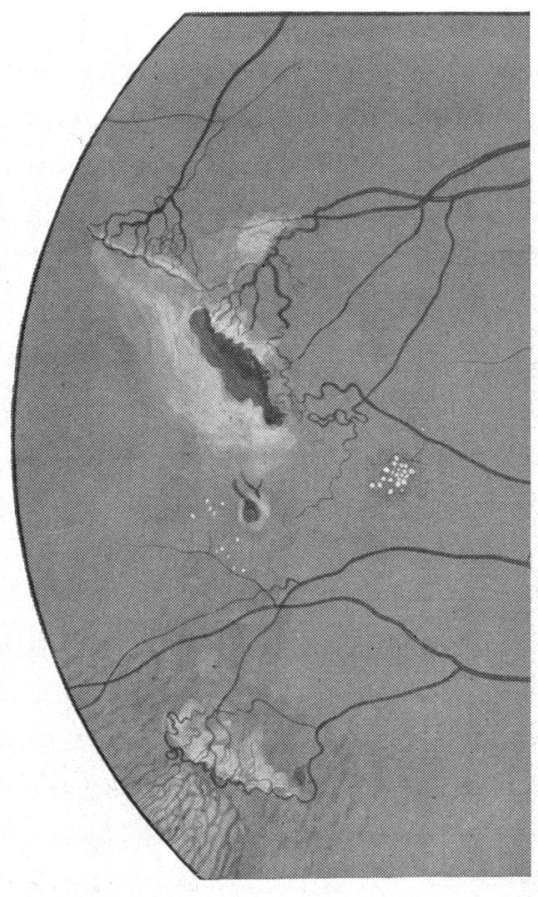

RIGHT EYE

Fig. 2(a).-Case 1, right eye, showing "red" area and terminal vascular arborizations in temporal retinal periphery. There is also a pigmented retinal scar and sub-retinal fibrosis in the area of the anastomotic communications.

Family History.-One brother (an electrophoretically proved case of sickle-cell haemoglobin $\mathrm{C}$ disease) had no ocular pathology but gave a history of bone and joint pains since childhood. There was splenomegaly, and some target cells in his peripheral blood smear.

Ophthalmological Examination (26.3.58)

Right Eye: Visual acuity hand movements at $2 \mathrm{ft}$. Anterior segment normal. Ocular tension normal. There was an almost total vitreous haemorrhage, but a thrombosed inferior temporal retinal vein could be seen at the periphery associated with some old choroido-retinal scarring.

Left Eye: Visual acuity $6 / 6$ with glasses. Media clear. Old choroido-retinal changes associated with thrombosed retinal veins at 2 o'clock.

General Examination.-No abnormality except for a slight splenomegaly.

\section{Laboratory Findings.}

Blood: $\mathrm{Hb} .106$ per cent.; colour index 1.9; white blood cells 5,700 c.mm., reticulocytes 3.5 per cent. (Counts done on alternate days range from 1 to 8 per cent.).

Blood Film: Rapid sickling occurred when incubation was carried out with a young culture of B. pyocyaneus. Target cells greatly increased. Circulating sickle cells 1 per cent.

Serum Electrophoresis: Abnormal haemoglobins S and C. 
Serum Bilirubin: Varied over 3 months between 0.4 and $1 \mathrm{mg}$. per cent.

Erythrocyte Sedimentation Rate: $2 \mathrm{~mm}$./hr.

Mantoux Reaction: Negative in all dilutions.

Blood Wassermann Reaction: Negative.

Urine: Slight excess of urobilinogen.

Stools: Nothing abnormal.

$X$-rays: Skull, chest, shoulders, and hips normal. Infarct in upper third of right tibia (Figs 3 and 4).

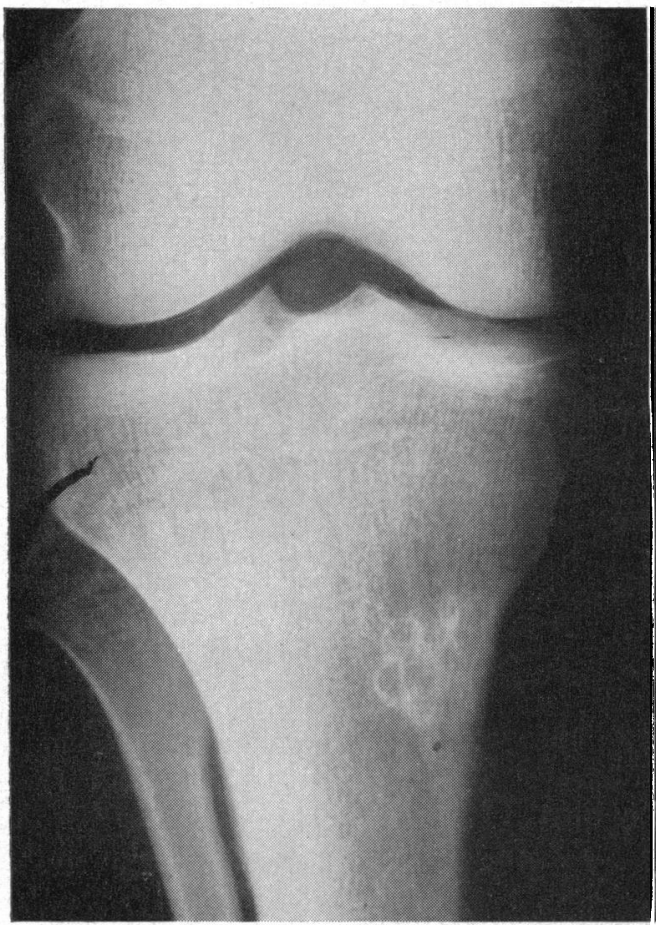

FIG. 3.-Case 2, upper third of right tibia, showing infarct.

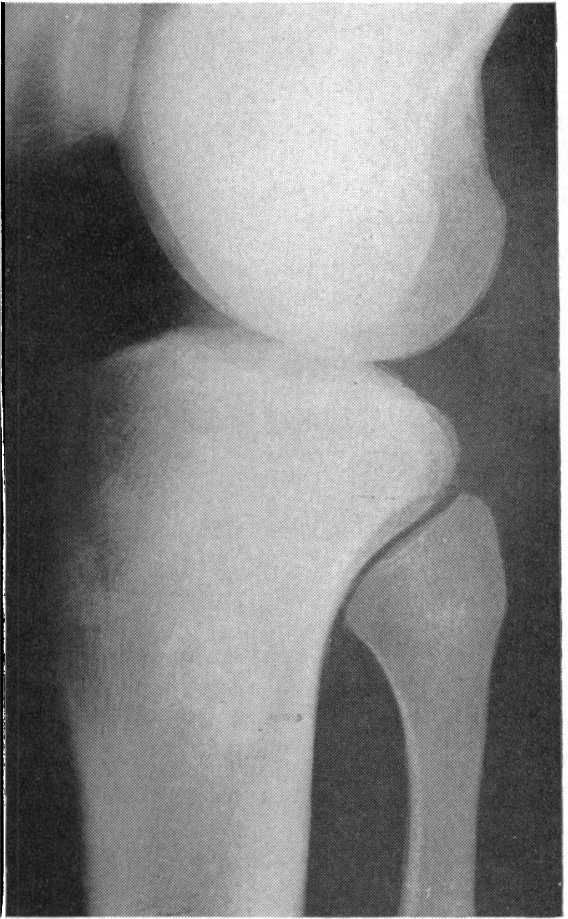

Fig. 4.-Case 2, upper third of right tibia (tranverse view).

Treatment.-On admission to hospital he was given a course of streptomycin and isoniazid for 2 weeks and later $500 \mathrm{mg}$. Diamox daily. Topical therapy consisted of atropine and prednisolone ointment twice daily to the right eye because low grade uveitis was present.

\section{Progress}

The right eye showed no evidence of absorption of the haemorrhage and the vitreous gave a yellowish reflex through the pupil. This eye became tender and hypotonic, with a heavy aqueous flare. The visual acuity fell to hand movements at $1 \mathrm{ft}$, but at an examination carried out on February 12, 1959, it had improved to counting fingers at $6 \mathrm{ft}$. The ocular tension was normal, although there was still a faint flare in the anterior chamber, and the vitreous had cleared sufficiently to show an extensive exudative retinal detachment.

The left eye, which had always appeared normal with the exception of the changes previously described, now showed slight fullness of the retinal veins and a clump of fresh haemorrhages in the nasal periphery. The visual acuity was $6 / 6$ with glasses. 
Case 3, a female Nigerian nurse aged 21 years, attended the casualty department in December, 1957, with a history of blurred vision in the left eye for the past 4 months.

Past History.-Haematuria in 1951. Frequent joint pains in knees, elbows, and shoulders, for as long as she could remember.

She had been investigated at another hospital 3 months before, and it had been found that she had peri-vasculitis, exudative detachments, and uveitis which was thought to be of tuberculous origin. A general examination had shown no abnormality except for hepatosplenomegaly. She had received a course of streptomycin, isoniazid and prednisolone, and more recently systemic Terramycin. The erythrocyte sedimentation rate and chest $x$ rays were normal, and the Mantoux test negative for all dilutions. Apart from a haemoglobin of 73 per cent. no abnormality was found in the blood.

Family History.-Father alive and well; mother died aged 30 and had always been in poor health.

Ophthalmological Examination.-Visual acuity 6/9 in the right eye and 6/12 in the left unaided. The anterior chambers showed cellular deposits on the posterior surfaces of the cornea. The fundi showed areas of retinal fibrosis at the periphery, anastomotic networks, haemorrhages, and sheathed vessels.

\section{Laboratory Findings}

Blood: Red cells 4 million per c.mm.; Hb. 73 per cent. (10.8 g. per cent.); colour index $0 \cdot 9$; packed cell volume 33 per cent.; mean corpuscular volume $82 \mathrm{cu} . \mu$; mean corpuscular haemoglobin concentration 32 per cent.; mean corpuscular haemoglobin $27 \gamma \gamma$.

* Blood Film: White cells no abnormality; red cells moderate anisocytosis with slight hypochromia and polychromasia. Numerous target cells (Fig. 5a). Anaerobic preparations showed marked sickling (Fig. $5 b$ ). Osmotic fragility decreased.

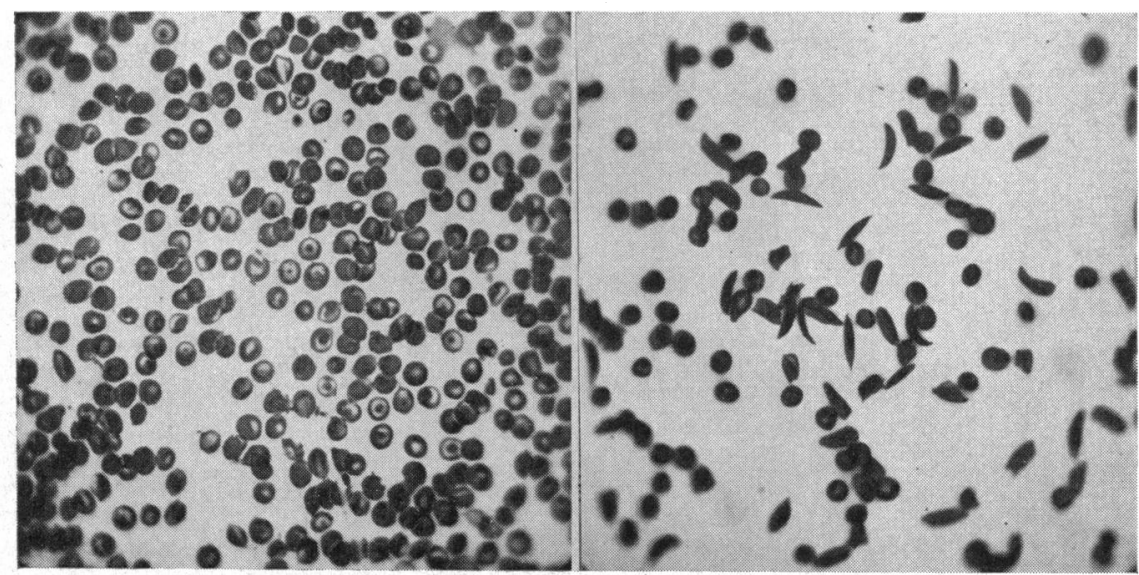

FIG. 5(a).-Case 3, blood smear, showing

Fig. 5(b).-Case 3, blood smear, showing target cells. $\times 645$. sickle cells. $\times 645$.

* Serum Electrophoresis: Haemoglobins S and C only.

Erythrocyte Sedimentation Rate: $15 \mathrm{~mm}$./hr. Blood Wassermann Reaction: Negative.

* When haemoglobin $\mathrm{C}$ is present, target cells are found in the greatest number in the peripheral smear. They are also found in the blood of cases with haemoglobin $\mathbf{E}$ and $\mathbf{S}$ and thalassaemia. Osmotic fragility is reduced more or less proportionally to the number of target cells. 
Progress.-Figs 6(a) and 6(b) show the fundus appearances of Case 3 in January, 1959. The visual acuity remained at $6 / 9$ in the right eye and $6 / 12$ in the left without glasses.

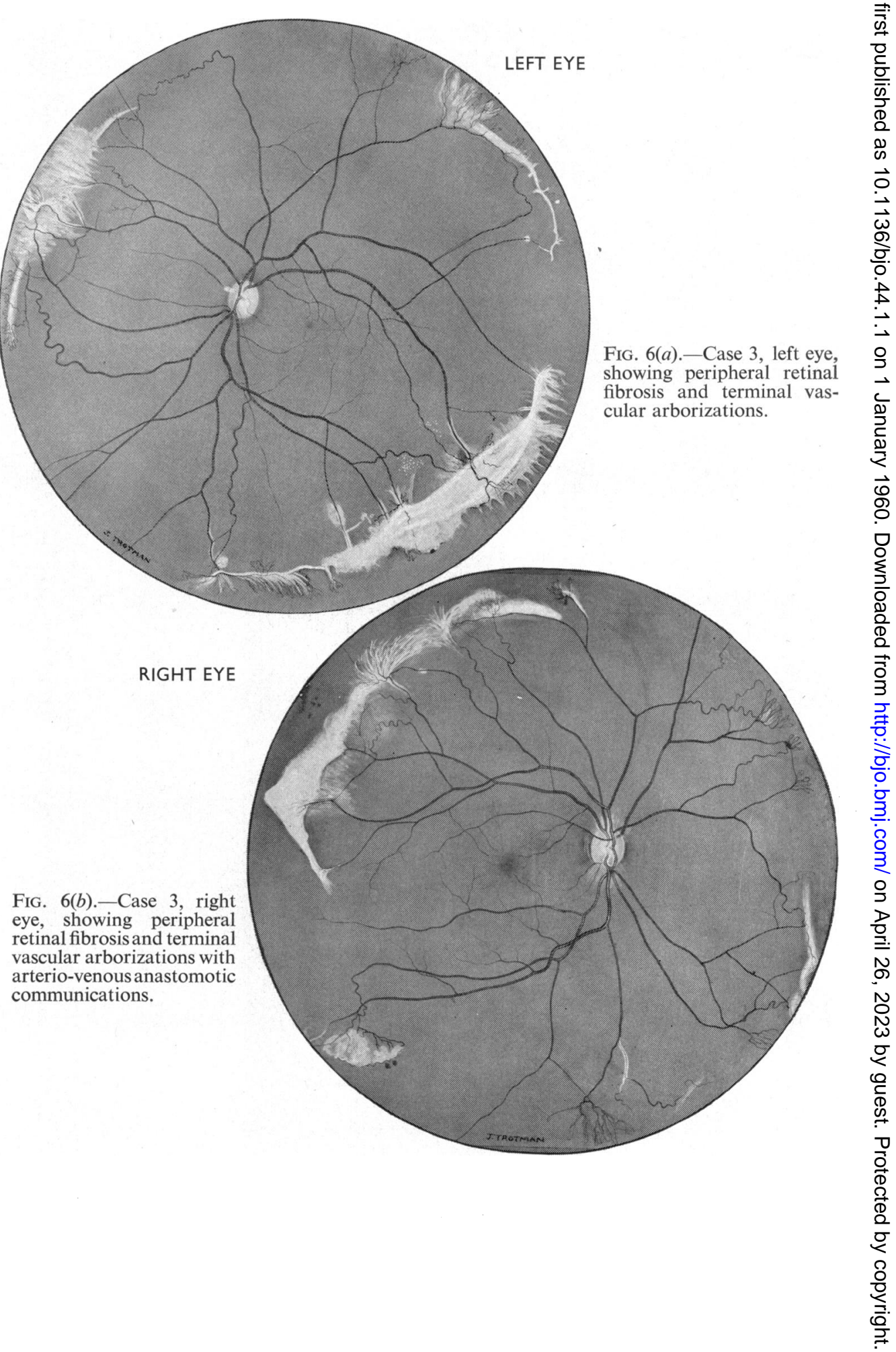


Case 4, a male Jamaican aged 28 years, first attended hospital in October, 1956, with loss of vision in the left eye for 6 days. No previous eye symptoms had been noted.

Past History.-Glandular fever, 1955. No history of rheumatic pains, haematuria, or any other symptoms suggesting episodes of infarction. No malaria. Acute otitis media also occurred in 1955 and a Kahn test carried out then was positive. Congenital syphilis was diagnosed at this time and a course of systemic penicillin and bismuth was given.

Family History.-One brother gave a history of splenectomy in 1955 for an "obscure haemolytic anaemia"; he was fully examined and the findings are given below (Case 5). The patient's sister and another brother were found to have haemoglobin AA and AC respectively.

\section{Ophthalmological Examination.}

Right Eye: Visual acuity 6/6 unaided.

Left Eye: Visual acuity could not be improved beyond 6/36 with a pin-hole lens. The vitreous was full of strands and coarse opacities behind which was a retinal detachment of indeterminate extent.

General Examination.-No abnormality. Spleen not felt.

\section{Laboratory Findings.}

Blood Count: Anaemia and leucocytosis.

Blood Film: Numerous target cells; sickling under anaerobic conditions.

Serum Electrophoresis: Approximately equal quantities of haemoglobins S and C.

$X$-rays: No abnormality.

Treatment.-A course of systemic cortisone with topical cortisone and atropine.

\section{Progress}

Left Eye: The diagnosis of a long-standing retinal detachment having been made, the patient was kept under observation. No change was observed in the next 2 years and the visual acuity remained at $6 / 36$.

Right Eye: In October, 1958, the patient experienced a cloud of floating opacities in this eye. The vitreous was clear with a small area of old choroiditis at 8 o'clock at the periphery. Within the month the visual acuity had fallen from $6 / 5$ to $6 / 12$ and a thin vitreous haemorrhage appeared. The periphery of the retina showed areas of fibrosis and haemorrhage with red patches simulating retinal tears. Tortuous "terminal" vessels with small superficial haemorrhages were also noted. Although the vitreous haemorrhage had increased by November, the periphery remains clearly visible and showed dense white areas in relation to peripheral retinal veins with some protrusion into the vitreous.

By the end of November, 1958, the vision in the right eye had returned to normal and the vitreous haemorrhage had cleared sufficiently for a view of the retina to be obtained. The "red" areas were no longer present, but pure white areas of retinal scarring were seen at the periphery in the nasal and temporal areas of the retina with telangiectatic vessel formation on their surfaces. The visual acuity was $6 / 6$. 
Fig. 7 shows the nasal periphery of the right fundus of Case 4 as it appeared in January, 1959. A "red" area is seen at 5 o'clock.

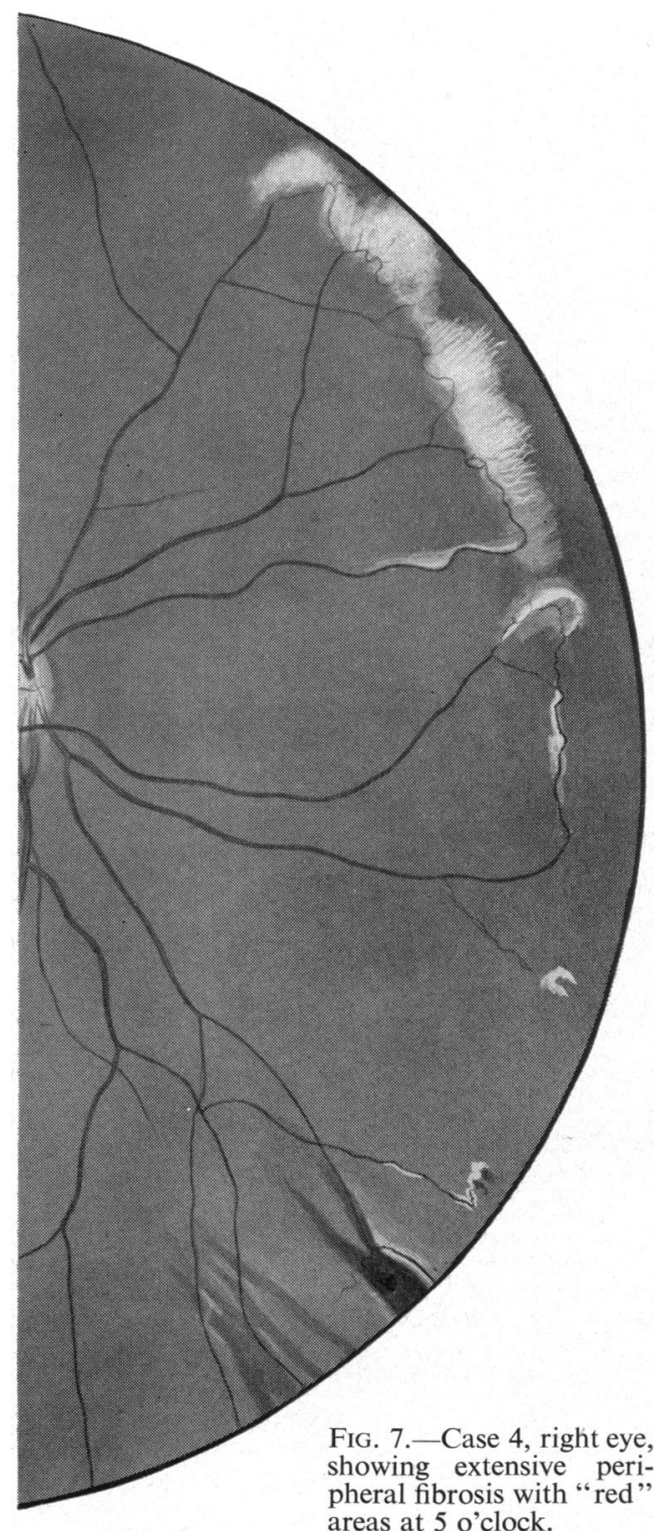

Case 5, a male Jamaican aged 34 years, was examined for fundus lesions because he was the brother of Case 4 .

Past History.-There had been a suggestion of pulmonary infarction in 1956 , the symptoms of which occasioned a visit to the Chest Clinic, where he complained of pleuritic pain and haemoptysis. No abnormality had been found, either clinically, radiologically, or in a Lowenstein sputum culture, but 6 months later his spleen had been removed because of persistent pain in the left hypochondrium, and hepato-splenomegaly was seen to be present.

He had had "rheumatism" in the fingers, and osteomyelitis of the left tibia had been noted in childhood. There was no history of malaria or of visual symptoms.

\section{Ophthalmological Examination.-}

The visual acuity was $6 / 5$ in both eyes. The media were clear. The right fundus showed anastomotic arcades of the peripheral retinal vessels, and the left showed typical brush-like tufts or networks of new vessels associated with areas of fibrosis in the nasal periphery.

\section{Laboratory Investigations}

Blood: Hb. 85 per cent.; white cells 10,000 per cu. mm; differential count normal; erythrocyte survival time normal.

Blood Film: No malarial parasites. Target cells very numerous. Marked sickling in a wet sealed preparation left standing overnight.

Serum Electrophoresis: Approximately equal quantities of abnormal haemoglobins $\mathbf{S}$ and $\mathbf{C}$.

Blood Wassermann Reaction and Gonococcal Complement-Fixation Test: Negative.

Liver Biopsy: Thickened capsule. Intralobular fibrous tissue unusually prominent. Scattered foci of inflammatory cells.

Spleen: Markedly congested, the capsule being thickened by fibrosis and deposition of fibrinoid material. 
Bone Marrow: Normal.

Splenic Phlebogram: Portal and splenic veins normal.

Case 6, a male Jamaican aged 28 years, complained of a gradual failure of vision in the left eye.

Past History.-Recurrent attacks of rheumatic pains in shoulders, back, and hips.

Family History.-Nothing relevant.

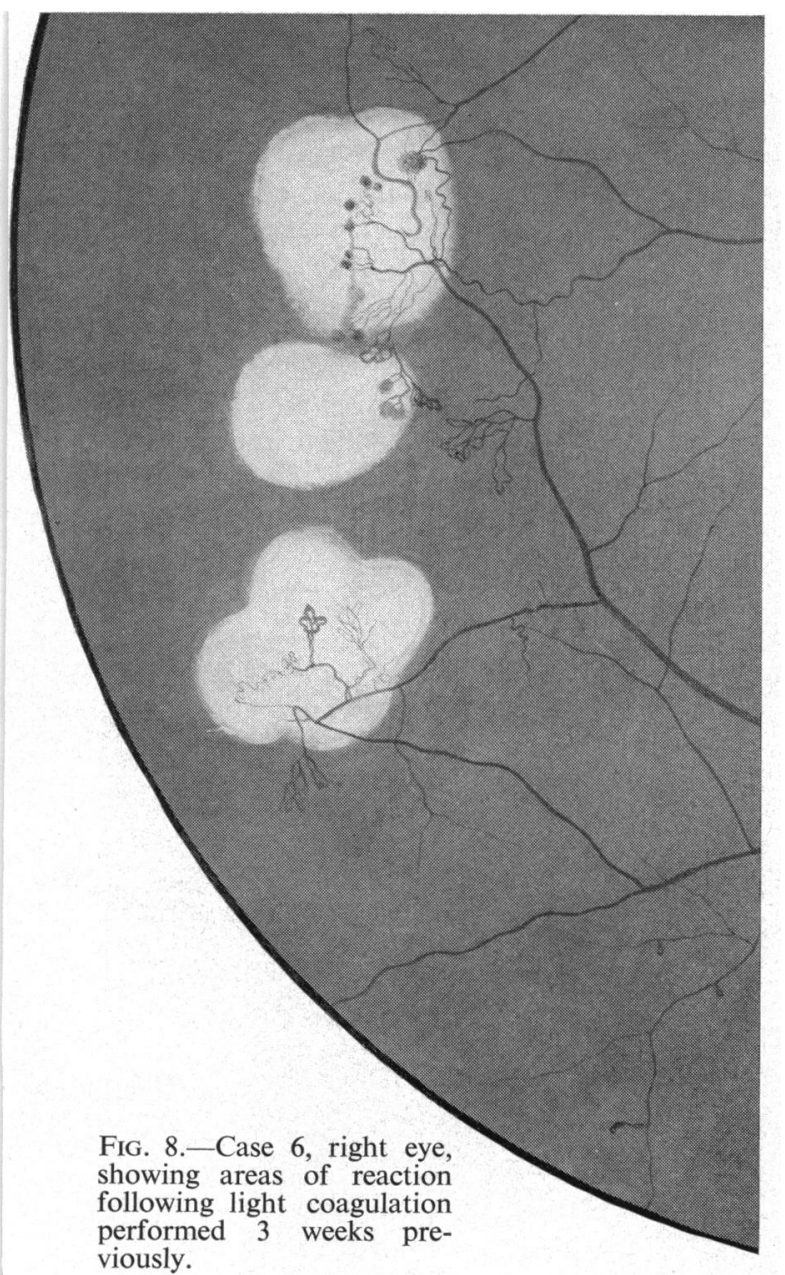

\section{Ophthalmological Examination}

Left Eye: There was an exudative retinal detachment inferiorly, but detailed examination of the fundus was difficult because of the presence of an immature cataract.

There was no evidence of uveitis and the visual acuity was perception of light in the temporal area.

Right Eye: The visual acuity was $6 / 6$, but a bunch of anastomotic vessels ending in bulbous dilations and surrounded by superficial haemorrhages was visible at the periphery at 8 o'clock.

General Examination.-No abnormality.

\section{Laboratory Findings}

Blood Count: Mild normochromic normocytic anaemia.

Blood Film: Numerous target cells. Anaerobic preparations showed marked sickling. Osmotic fragility decreased.

Serum Bilirubin: $0.1 \mathrm{mg}$. per cent.

Serum Electrophoresis: Abnormal haemoglobins $\mathrm{S}$ and $\mathrm{C}$ only.

$X$-rays: Skull, shoulders, hips, and long bones normal.

Treatment.-The anastomotic vessels in the temporal periphery have since been treated by light coagulation (Fig. 8).

Cases 7 and 8 are typical of sickle-cell haemoglobin $\mathrm{C}$ disease, but in these cases the diagnosis was not proved by electrophoresis.

Case 7, a male Nigerian aged 28 years, first attended in May, 1953, complaining of a "floater" in the left eye. 
Ophthalmological Examination.-The visual acuity was 6/6 in each eye with clear mediae, but at the periphery of the right fundus discrete red "punched-out" areas were seen simulating retinal tears. Most of the peripheral retinal veins had a brush-like termination. The left fundus showed a peripheral ridge of fibrosis temporally.

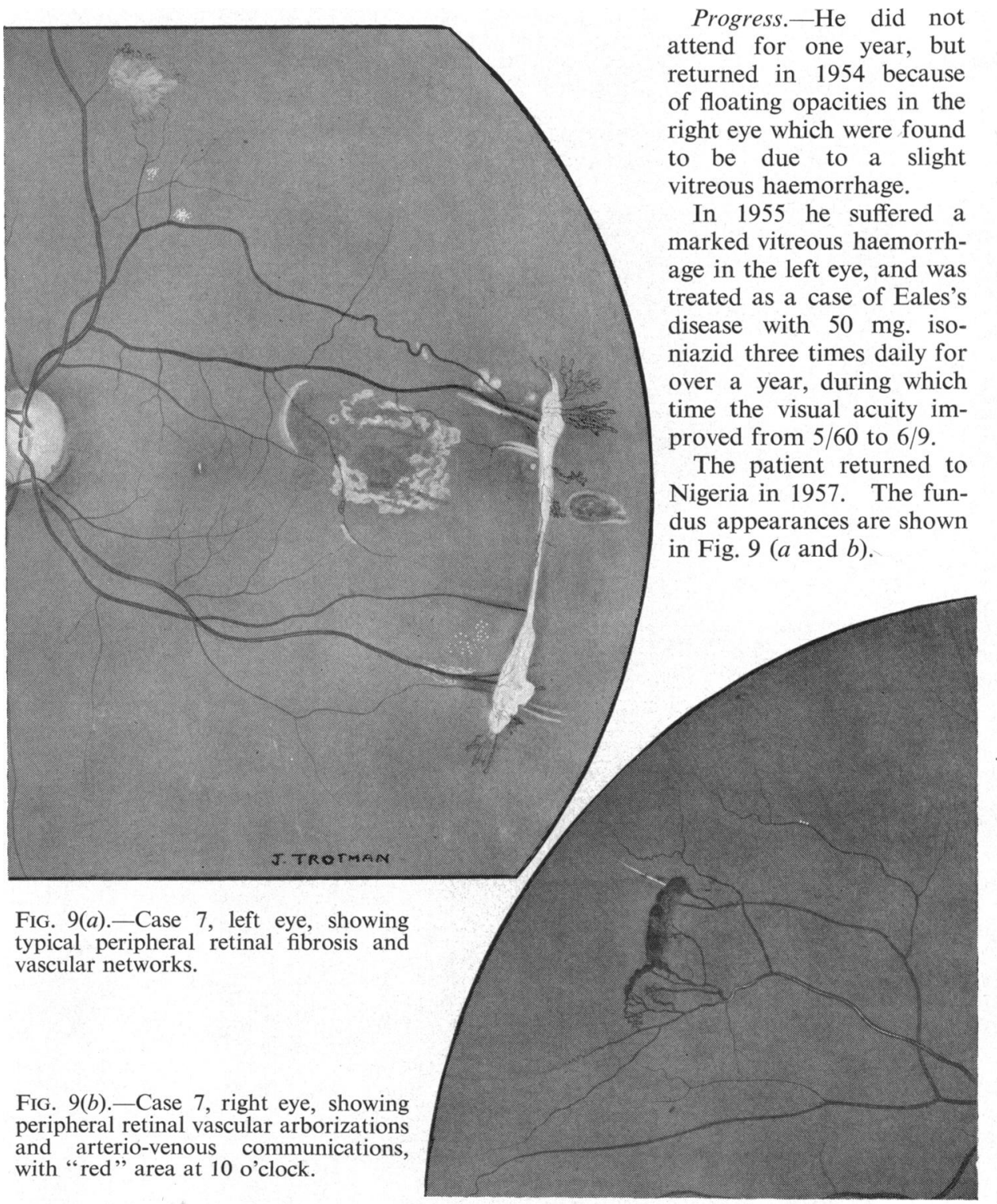

\section{Laboratory Findings (1957)}

Blood Count: Normal.

Blood Film: Numerous target cells. Slight anisocytosis and hypochromia. Moderate sickling in anaerobic preparations. 
Case 8, a male Jamaican aged 26 years, first attended in February, 1955, complaining of sudden blurring of vision in the left eye 2 weeks previously.

Past History.-No previous illnesses reported.

Family History.-Nothing relevant.

Ophthalmological Examination.-The visual acuity was 6/12 in the right eye and 6/18 in the left unaided. Bilateral vitreous opacities were present but there were no cells in the anterior chambers. Extensive bilateral retinal changes could be seen and these are shown diagrammatically in Fig. 10.

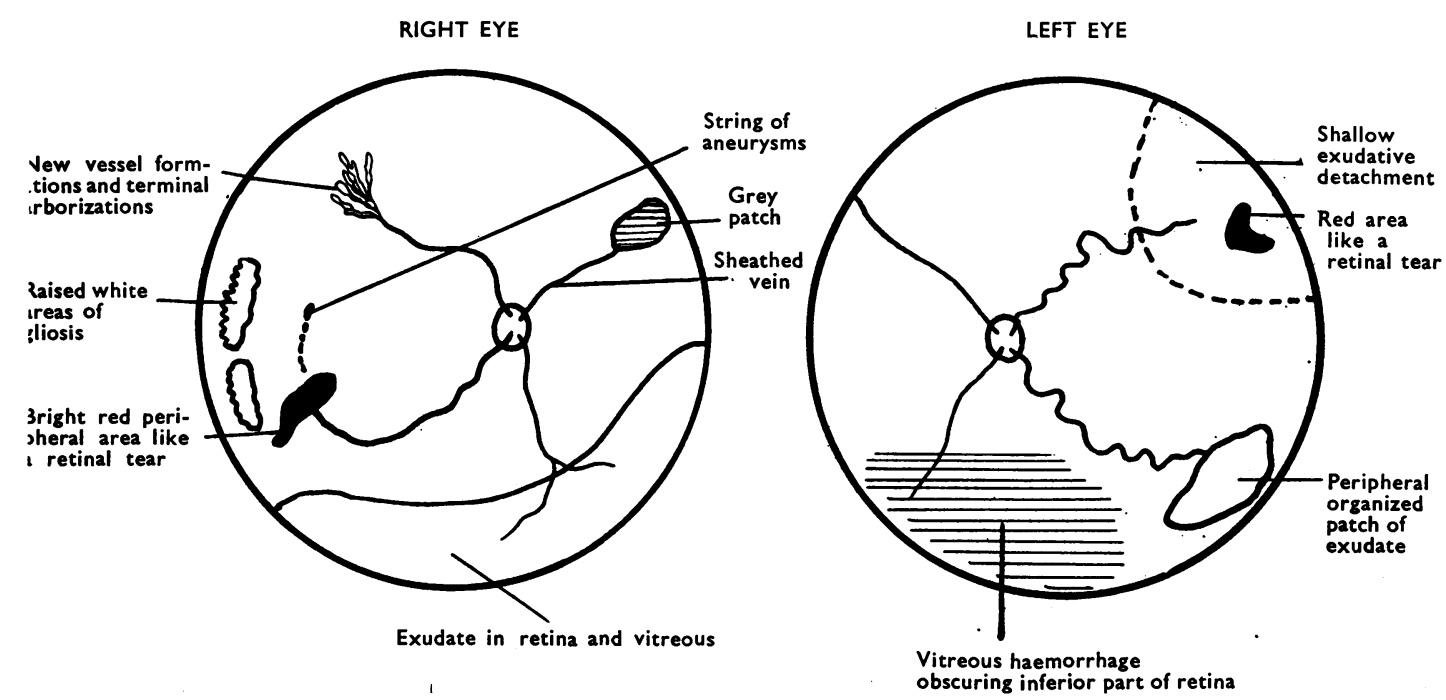

FIG. 10.-Case 8, diagram of bilateral retinal changes.

General Examination.-No abnormality.

\section{Laboratory Findings}

Blood Count: Normal. 24 hrs.

Blood Film: Numerous target cells; anisocytosis; poikilocytosis; 100 per cent. sickling after

Blood Wassermann Reaction, Kahn Test, and Gonococcal Complement-Fixation Test: Negative.

Brucellosis Agglutination Test: Negative.

Toxoplasmosis Complement-Fixation Test: Negative.

$X$-rays: Skull and chest normal.

Progress.-He was kept under observation until August, 1955, when he returned to Jamaica. The visual acuity was then $6 / 9$ in the right eye, and 6/18 in the left. The vitreous had cleared but the fundus appearances were almost unchanged, except that the oedema had subsided and there was more peripheral retinal fibrosis. 
Case 9, a female Jamaican aged 32 years, first attended in September, 1959, complaining of deterioration of vision of the right eye over the past 2 years.

\section{Past History}

Obstetric.-A normal confinement in 1945. Two incomplete abortions in 1953. In 1954, when she was 35 weeks pregnant, the patient had a severe crisis characterized by widespread joint pains with pyrexia and pneumonic consolidation which was considered to be embolic in origin. This was reported by Bannerman and White (1957).

Vascular.-Repeated painful vascular lesions in the toes in cold weather, much improved by lumbar sympathectomy.

Family History.-The husband has normal haemoglobins. The child of the last pregnancy (1957) has the $C$ trait although he could equally well have inherited the abnormal haemoglobin $\mathrm{S}$ from his mother to obtain the sickle cell-trait.

\section{Ophthalmological Examination}

Right Eye: Visual acuity counting fingers. Peripheral lesions characteristic of sickle-cell haemoglobin $\mathrm{C}$ disease ("red" areas, fibrous tissue, and aneurysmal dilations) were seen all round the periphery. The macula showed a "hole" formation which was probably secondary to previous posterior uveitis.

Left Eye: Visual acuity 6/9. Similar peripheral vascular changes were seen. A very large "red" area extending from 4 to 7 o'clock simulating a retinal dialysis disappeared within 3 weeks. There was also a thin vitreous haemorrhage which was described as a "floater" by the patient. One week later no fundus details could be seen because of a dense vitreous haze which appeared to be due not only to haemorrhage but also to posterior uveitis.

\section{Laboratory Findings}

Blood: Hb. 87 per cent. (12.89 per cent.), white cell count normal.

Blood Film: Anisocytosis and hypochromasia. Numerous target cells. Anaerobic preparations showed sickling after $30 \mathrm{~min}$. with 2 per cent. sodium bisulphite.

Serum Electrophoresis: Abnormal haemoglobins $\mathbf{S}$ and $\mathrm{C}$.

Erythrocyte Sedimentation Rate: Normal.

Stools: Occult blood.

$X$-rays: Chest, tibia, and feet normal.

Treatment.-The patient was admitted for a course of systemic prednisolone (initially $40 \mathrm{mg}$. per day) and Diamox (7 mg. per kg. body weight daily). Topical therapy consisted of atropine and prednisolone.

Progress. - While under this treatment the patient complained of excruciating pain in the right elbow which was only partly relieved by pethidine. $X$-rays of this region showed small dense areas in the interior of the lower end of the right humerus. These were considered consistent with tiny infarcts, although but for the patient's medical history these lesions might have been passed over as islands of dense bone which are not uncommon in normal subjects (Fig. 11, opposite).

The vitreous of the left eye cleared completely except for a white posterior vitreous opacity which floated about in front of the macula. All the "red" areas disappeared and the periphery of the fundus seemed to have fewer areas of fibrosis. The visual acuity was $6 / 12$ when the patient was discharged after one month's treatment. 


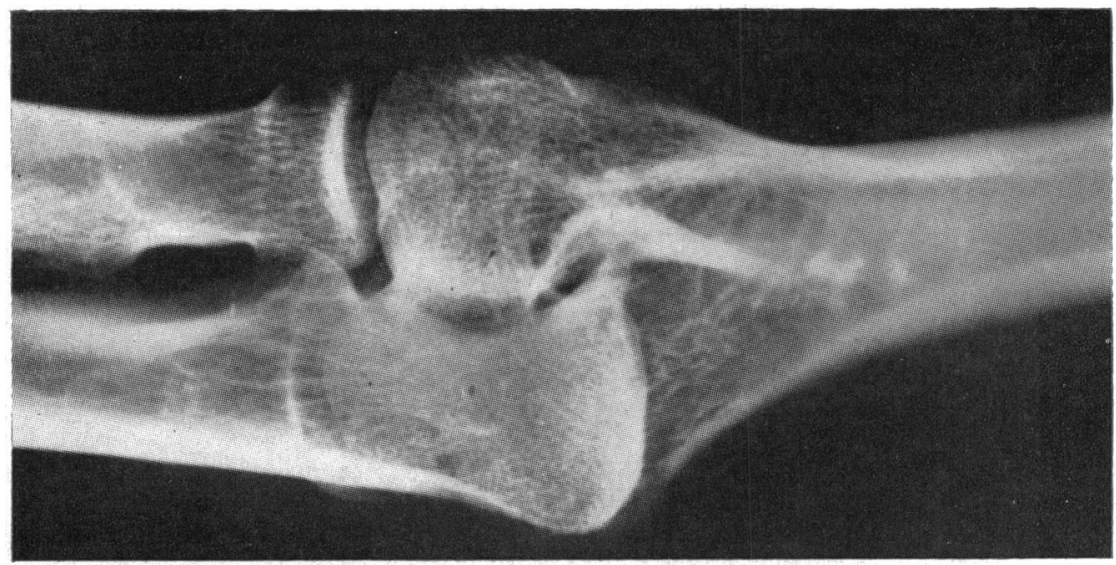

Fig. 11.-Case 9, right humerus, showing infarct.

\section{Discussion}

Of nine Negro patients aged between 20 and 30 years with ocular complications, seven were proved by electrophoresis to have sickle-cell haemoglobin $\mathrm{C}$ disease. The fundus appearances are identical with those previously described in the literature. The nine cases are summarized in Table III (overleaf).

The disease may be symptomless from both the general and the ocular standpoint. The clinical diagnosis was made on the fundus appearance alone by Smith and Krevans (1959). Ocular complications have so far been described by Edington and Sarkies (1952), Smith and Conley (1954), Hannon (1956), Kennedy and Cope (1957), Goodman and others (1957), Isbey and others (1958), and Smith and Krevans (1959). All these were proved by electrophoresis to be cases of sickle-cell haemoglobin $\mathrm{C}$ disease, but other writers have reported ocular changes typical of those found in the proven disease. Henry and Chapman (1954) divided 29 cases into two groups, one with sickling and anaemia and the other with sickling without anaemia. The criteria for the anaemia, which would not have been completely satisfied by any of the cases reported here, were a red cell count of less than 3.5 million, haemoglobin of less than $11 \mathrm{gm}$., serum bilirubin of less than $1 \mathrm{mg}$., and a reticulocyte count of more than 1 per cent. Five patients in the first group and four cases in the second showed recurrent vitreous haemorrhages, peripheral gliosis, and choroido-retinal scarring. Electrophoretic studies were not carried out, but it is interesting that Goodman and others (1957) later proved one of these to be a case of sickle-cell haemoglobin $\mathrm{C}$ disease and included it in their own series. Rudd, Evans, and Peeney (1953) reported ocular complications in a cast of thalassaemia minor, but later investigations showed latent sickling of the patient's red cells. This man came from West Africa where there is a high incidence of haemoglobin $\mathrm{C}$. 
TABLE III CLINICAL

\begin{tabular}{|c|c|c|c|c|c|}
\hline \multicolumn{2}{|l|}{ Case No. } & 1 & 2 & 3 & 4 \\
\hline \multicolumn{2}{|l|}{ Age (yrs) } & 29 & 24 & 21 & 27 \\
\hline \multicolumn{2}{|c|}{ Country of Origin } & Ghana & Ghana & Nigeria & Jamaica \\
\hline \multicolumn{2}{|l|}{ Sex } & Male & Male & Female & Male \\
\hline \multicolumn{2}{|c|}{$\begin{array}{l}\text { Reason for } \\
\text { Examination }\end{array}$} & $\begin{array}{l}\text { Refraction } \\
\text { No symptoms }\end{array}$ & $\begin{array}{l}\text { Injury followed by } \\
\text { loss of vision } \\
\text { right eye }\end{array}$ & $\begin{array}{l}\text { Blurred vision } \\
\text { left eye }\end{array}$ & $\begin{array}{l}\text { Loss of vision } \\
\text { left eye }\end{array}$ \\
\hline \multicolumn{2}{|c|}{$\begin{array}{l}\text { History of } \\
\text { Rheumatism }\end{array}$} & + & + & + & - \\
\hline \multicolumn{2}{|c|}{ Haematuria } & - & - & + & - \\
\hline \multicolumn{2}{|c|}{$\begin{array}{l}\text { General } \\
\text { Examination }\end{array}$} & Splenomegaly & $\begin{array}{l}\text { Splenomegaly } \\
\text { Bone infarct }\end{array}$ & $\begin{array}{l}\text { Hepato- } \\
\text { splenomegaly }\end{array}$ & - \\
\hline \multicolumn{2}{|c|}{$\begin{array}{l}\text { Principal Features } \\
\text { of Ocular } \\
\text { Pathology }\end{array}$} & $\begin{array}{l}\text { Right: Varicose } \\
\text { "terminal" dila- } \\
\text { tations } \\
\text { "Red" area } \\
\text { Fibrosis } \\
\text { Left: Total vitreous } \\
\text { haemorrhage }\end{array}$ & $\begin{array}{l}\text { Right: } \text { Vitreous } \\
\text { haemorrhage } \\
\text { Exudative retinal } \\
\text { detachment } \\
\text { Both: Peripheral } \\
\text { choroido-retinal } \\
\text { scarring and } \\
\text { thrombosed } \\
\text { retinal veins }\end{array}$ & $\begin{array}{l}\text { Both: Peripheral } \\
\text { retinal fibrosis } \\
\text { and sheathing }\end{array}$ & $\begin{array}{l}\text { Left: Old retinal } \\
\text { detachment } \\
\text { Right: Vitreous } \\
\text { haemorrhage } \\
\text { "Terminal" } \\
\text { anastomoses } \\
\text { "Red" areas } \\
\text { Fibrosis }\end{array}$ \\
\hline \multirow{2}{*}{$\begin{array}{l}\text { Ultimate } \\
\text { Visual } \\
\text { Acuity }\end{array}$} & Right & $6 / 5$ & Counting fingers & $6 / 9$ & $6 / 6$ \\
\hline & Left & $6 / 12$ & $6 / 6$ & $6 / 12$ & $6 / 36$ \\
\hline \multicolumn{2}{|c|}{$\begin{array}{l}\text { Anisocytosis and } \\
\text { Poikilocytosis }\end{array}$} & + & + & + & + \\
\hline \multicolumn{2}{|c|}{ Target Cells } & ++ & ++ & ++ & ++ \\
\hline \multicolumn{2}{|c|}{ Latent Sickling } & 25 per cent. & Marked & Marked & Marked \\
\hline \multicolumn{2}{|c|}{ Electrophoresis } & $\mathrm{S}$ and $\mathrm{C}$ & $\mathrm{S}$ and $\mathrm{C}$ & $\mathrm{S}$ and $\mathrm{C}$ & $\mathrm{S}$ and $\mathrm{C}$ \\
\hline
\end{tabular}

The retinopathy of sickle-cell haemoglobin $\mathrm{C}$ disease is confined mainly to the periphery, which may explain why it may be overlooked in a routine ophthalmoscopic examination without dilatation of the pupil.

The characteristic appearances are the following:

(1) Arterio-venous anastomotic communications with terminal bulbous or varicose dilatations.

(2) Brush-like terminations of the peripheral retinal capillaries and new vessel formation.

(3) Peripheral areas of choroido-retinal atrophy.

(4) Peripheral fibrosis.

(5) Curious "red" areas which have been ascribed to thin pre-retinal or sub-retinal haemorrhages. 
FINDINGS IN NINE CASES

\begin{tabular}{|c|c|c|c|c|}
\hline 5 & 6 & 7 & 8 & 9 \\
\hline 23 & 28 & 28 & 26 & 32 \\
\hline Jamaica & Jamaica & Nigeria & Jamaica & Jamaica \\
\hline Male & Male & Male & Male & Female \\
\hline Brother of Case 4 & $\begin{array}{l}\text { Gradual failure of } \\
\text { vision left eye }\end{array}$ & "Floater" left eye & $\begin{array}{l}\text { Blurred vision left } \\
\text { eye }\end{array}$ & $\begin{array}{l}\text { Blurred vision } \\
\text { both eyes }\end{array}$ \\
\hline+ & - & - & - & + \\
\hline- & - & - & - & - \\
\hline $\begin{array}{l}\text { Hepato- } \\
\text { splenomegaly }\end{array}$ & - & - & - & $\begin{array}{l}\text { Splenomegaly } \\
\text { Bone infarct }\end{array}$ \\
\hline $\begin{array}{l}\text { Left: Peripheral } \\
\text { retinal tufts of } \\
\text { new vessels and } \\
\text { fibrosis } \\
\text { Right: Anastomotic } \\
\text { arcades of } \\
\text { peripheral vessels }\end{array}$ & $\begin{array}{l}\text { Right: "Terminal" } \\
\text { anatomoses } \\
\text { Left: Exudative } \\
\text { retinal detach- } \\
\text { ment } \\
\text { Immature } \\
\text { cataract }\end{array}$ & $\begin{array}{l}\text { Right: "Red" } \\
\text { punched-out } \\
\text { areas } \\
\text { Peripheral } \\
\text { retinal tufts of } \\
\text { new vessels } \\
\text { Left: Peripheral } \\
\text { fibrosis } \\
\text { Both: Vitreous hae- } \\
\text { morrhage later }\end{array}$ & $\begin{array}{l}\text { Both: Vitreous } \\
\text { haemorrhage } \\
\text { "Red" areas } \\
\text { Peripheral new } \\
\text { vessel formation, } \\
\text { fibrosis, and } \\
\text { sheathing } \\
\text { Left: Exudative } \\
\text { retinal } \\
\text { detachment }\end{array}$ & $\begin{array}{l}\text { Both: Vitreous } \\
\text { haemorrhage } \\
\text { and cellular } \\
\text { infiltration } \\
\text { Peripheral } \\
\text { retinal fibrosis } \\
\text { New vessel } \\
\text { formation } \\
\text { "Red" areas }\end{array}$ \\
\hline $6 / 5$ & $6 / 6$ & $6 / 6$ & $6 / 9$ & $6 / 60$ \\
\hline $6 / 5$ & Perception of light & $6 / 9$ & $6 / 18$ & $6 / 12$ \\
\hline Slight & + & + & + & + \\
\hline++ & ++ & ++ & ++ & ++ \\
\hline Marked & Marked & Moderate & 100 per cent. & $\begin{array}{l}\text { Marked and rapid } \\
75 \text { per cent. }\end{array}$ \\
\hline $\mathrm{S}$ and $\mathrm{C}$ & $\mathrm{S}$ and $\mathrm{C}$ & Not done & Not done & $\mathrm{S}$ and $\mathrm{C}$ \\
\hline
\end{tabular}

(6) Thrombosed peripheral retinal veins.

(7) Exudative retinal detachment.

Vitreous haemorrhage, uveitis, and cataract may be additional complications. Vitreous haemorrhage may occur some years after the first appearance of the retinal vascular lesions. The retinopathy may be present without any diminution of the visual acuity.

These ocular complications have been confirmed by Edington and Sarkies (1952), who described peripheral morula-shaped micro-aneurysmal dilatations and vitreous haemorrhage. Smith and Conley (1954), in their admirable paper on the clinical features of the genetic variants of sickle-cell disease, reported that three of the sixteen patients with sickle-cell haemoglobin $\mathrm{C}$ 
disease had had one or more episodes of vitreous haemorrhage. One of their patients had peculiar aneurysmal dilatations at the macular region, and this eye suffered vitreous haemorrhage one year later. The fellow eye, reported as normal then, later developed similar changes in the macular region. Hannon (1956) reviewed 140 cases of "sickle-cell disease" seen between 1936 and 1952. After electrophoresis had been carried out on some of these, twenty cases of sickle-cell haemoglobin $\mathrm{C}$ disease were revealed, seven of them with vitreous haemorrhages. Of 62 with the sickle-cell trait, only one had a fundus abnormality which consisted of dilated retinal veins. Sickle-cell anaemia was found in 53 cases, and 25 of these had dilated tortuous retinal veins, but in none was there any retinopathy or vitreous haemorrhage. Hannon described the earliest vascular abnormality, in his series of sickle-cell haemoglobin $\mathrm{C}$ disease, as the appearance of neovascular anastomotic networks of five vessels, with corkscrew venules arranged in multiple arborizing formations projecting into the vitreous. The latter were thought to be the site of ultimate bleeding. Occluded peripheral temporal veins and raised whitish peripheral plaques of glial tissue were also described. Kennedy and Cope (1957) described peripheral retinal gliosis and recurrent vitreous haemorrhages in one case but also noted dilated retinal veins. These seem uncommon in sickle-cell haemoglobin $\mathrm{C}$ disease but rather more likely in sickle-cell anaemia where the heart is dilated and there is a high cardiac output. This case progressed finally to uveitis and hypotony. Isbey and others (1958) described three cases with spontaneous vitreous haemorrhages, peripheral exudative detachments, gliosis, and occluded peripheral vessels, but were unable to corroborate the usually prevalent terminal vascular arborizations. In one of their cases, operation of the retinal detachment failed and the eye was later enucleated.

Goodman and others (1957) reported fundus changes similar to those described in this paper when they recorded four cases of sickle-cell haemoglobin C disease. In one case the "red" areas changed position repeatedly and disappeared after a few days. Vascular loops projecting into the vitreous confirmed the earlier findings of Hannon (1956), and fibrous tissue proliferation, exudative detachments, and terminal bulbous dilatations completed the typical picture. Aneurysmal dilatations of the conjunctival vessels, also seen in Case 1 of this series (Fig. 12), were illustrated.

Frg. 12.-Case 1, left eye, showing aneurysmal dilatation of conjunctival vessel.

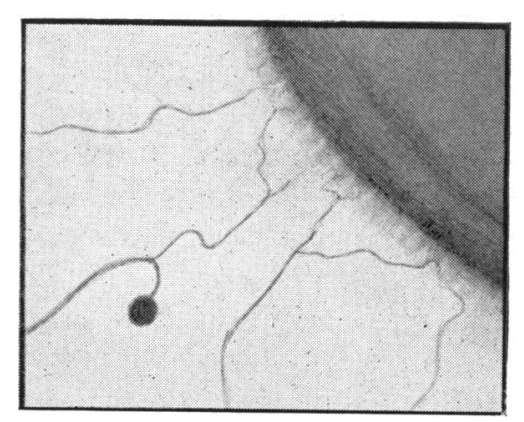


Complicated cataract also occurred as in Case 6. Smith and Krevans (1959), in a survey of 43 cases, found eight with the typical ocular changes previously described; eight had aseptic necrosis of the hip, three had haematuria, and nine out of thirteen had increased morbidity or mortality associated with pregnancy.

It is curious that no case of vitreous haemorrhage has so far been described in a case of sickle-cell anaemia, proved by electrophoresis, despite the higher incidence of thrombotic episodes elsewhere in the body, although four instances were described in patients with the sickle-cell trait by Isbey and others (1958). This is certainly a relatively common complication in sicklecell haemoglobin $\mathbf{C}$ disease, as the cases reported in this paper tend to confirm.

Sickle-cell haemoglobin C disease resembles Eales's disease in that recurrent vitreous haemorrhages are characteristic in both. The age group is approximately the same. However, where retinal detachment in the former is exudative, in the latter it is usually due to traction. In the external haemorrhagic retinitis of Coats, there is also some resemblance both in the age group and in the clinical appearance. Glomerular-like tufts, anomalous anastomoses, and spiral tortuosities of the vessels may be seen (Duke-Elder, 1940), but the organized sub-retinal haemorrhages in sickle-cell haemoglobin $\mathrm{C}$ disease are peripheral, whereas in Coats's disease although the periphery may be affected the posterior pole is also involved. Characteristically there is no vitreous haemorrhage in Coats's disease. Reese (1956) considered Coats's disease to be basically a more or less masked telangiectasis of retinal vessels. Occlusion of retinal veins caused by sub-endothelial deposition of a polysaccharide causes new vessel formation with aneurysmal dilatations. Conglomerate masses of these micro-aneurysms simulate telangiectasis clinically. These abnormal vessels described by Reese were dispersed throughout the retina with the retinal tissue as their stroma. Angiomatosis retinae may also simulate the retinopathy of sickle-cell haemoglobin $\mathrm{C}$ disease.

Infarction of end arteries produces characteristic radiological changes in sickle-cell haemoglobin $\mathrm{C}$ disease. These may occur at the head of the femur causing necrosis simulating Perthe's disease and Caisson disease. The infarct at the upper third of the tibia in Case 2 occurred at a site usual for a Brodie's abscess and also for embolic mycetoma (Abbott, 1959). By the time the infarct is discovered radiologically, however, it may be some distance from the metaphysis where it originally began as a result of growth having taken place at the epiphyseal line. Phemister (1940) describes a bone infarct at this site in a case of generalized arteriosclerosis. The radiological appearance is identical. Infarction probably occurs in this area because this is the site for end arteries with poor anastomosis between them. Harris, H. A. (1929) stated that the phenomena of disease in the juxta-epiphyseal zone or metaphysis are essentially phenomena of infarction and that infarction in bone does not differ, in any essential manner, from infarction in other organs supplied 
by end arteries. Although Harris mentioned only the lung, liver, spleen, kidney, and brain, all of which can be involved in sickle-cell haemoglobin C disease, he might well have added the eye.

In time, a small bone infarct may be reduced in size by new bone substitution and it may ultimately be replaced completely in the diaphysis, but in the shafts large infarcts are walled off by fibrous tissue which gives a sharp line of demarcation when ossified (Phemister, 1940).

Two fatal cases of sickle-cell haemoglobin $\mathrm{C}$ disease were reported by Smith and Krevans (1959), one of which had massive bone marrow emboli in the lungs and fat emboli in the brain and kidney, while the other had multiple small thrombi in the pulmonary arteries and areas of pulmonary necrosis.

Death due to a crisis in a 48-year-old Negress with sickle-cell disease was reported by Diggs and Jones (1952); they considered that the contributory factor was an alcoholic bout. This patient was carrying out a full day's work cotton picking shortly before her death, which was due to multiple thromboses and focal necrosis in brain, lungs, bone marrow, and liver. No large arteries or venous sinuses were thrombosed, but sickle cells distended the capillaries in all areas.

The authors point out that in sickle-cell anaemia the thromboses are of the larger dural veins and meningeal arteries with involvement of the grey matter, whereas in their patient with sickle-cell haemoglobin C disease the haemorrhages occurred in the small vessels of the white matter. Perhaps this is why one does not see the peripheral retinopathy in sickle-cell anaemia, but only in the sickle-cell trait or disease where the capillaries are solely affected.

The increased morbidity or mortality associated with pregnancy is probably greater than in any other haemoglobinopathy.

General anoxaemia, whether due to anaesthesia, high altitudes, pneumonia, or diminished oxygenation of the lungs (even if this is due to drugs or the stupor following an alcoholic bout), may precipitate a sickling crisis.

The importance of recognizing this disease, which can maim, blind, or even kill given unfavourable conditions, cannot therefore be over-emphasized.

Although electrophoresis may be impracticable as a routine investigation, the staining of peripheral blood smears or examination for latent sickling is possible and should be done in Negroes with any symptoms suggestive of an infarctive episode. Examination of the peripheral fundus also may reveal signs of capillary occlusion which may be symptomless and therefore a useful adjunct in the confirmation of sickle-cell haemoglobin $\mathrm{C}$ disease. Such an examination should always be included at the first ante-natal visit. Prevention of further complications could also include oxygen inhalation to combat local anoxaemia (Bauer, 1940), diathermy to the retinal sites presumed to be ultimate sources of intra-ocular haemorrhage (Hannon, 1956), avoidance of anoxaemia, and Diamox given in doses of $250 \mathrm{mg}$. per day.

There is some evidence that Diamox reduces the number of sickling episodes in sickle-cell anaemia, but this has not been demonstrated so far in 
sickle-cell haemoglobin C disease. Charmot and Raynaud (1958) treated ten children with Diamox (5-10 mg./ kg. body weight) and found that they had shorter and less painful crises than forty controls also suffering from sicklecell anaemia. Hilkovitz (1957) described the mode of action of this drug which, by its inhibition of the tissue carbonic anhydrase, lowers the plasma $\mathrm{CO}_{2}$ level and therefore the oxyhaemoglobin dissociation is suppressed.

Fowler, Smith, and Greenfield (1957) found that all the patients they studied who had sicklaemia showed a reduction in arterial oxygen saturation. Oxygen saturation of sickle and normal haemoglobin at comparable tensions and $\mathrm{pH}$ showed a consistently lower uptake of oxygen by sickle haemoglobin.

The pulmonary defect found in their cases of sickle-cell anaemia (which is not seen in sickle-cell haemoglobin $\mathrm{C}$ disease) was considered to be one factor in the difficulty in maintaining a normal alveolar-arterial oxygen tension gradient. The dissociation curve of oxyhaemoglobin is therefore displaced to the right of normal. Wyman and Allen (1951) found however that dialysed sickle-cell haemoglobin had the same oxygen dissociation curve as normal haemoglobin similarly prepared. This suggested the defect does not occur in the haemoglobin itself but in the red blood cell. The possibility of a reduced $\mathrm{pH}$ in the red blood cell was postulated.

According to a leading article in the Lancet (1957), patients with 50 to 80 per cent. haemoglobin $\mathrm{S}$, such as is found in sickle-cell haemoglobin $\mathrm{C}$ disease where the proportions of haemoglobin $\mathrm{S}$ and $\mathrm{C}$ are equal, may show sickling at an oxygen partial pressure of $40 \mathrm{~mm}$. This may therefore occur at 4,000 to $6,000 \mathrm{ft}$ in unpressurized aircraft. Several cases of splenic infarction occurring during an aeroplane flight have been recorded amongst Negroes suffering from the sickle-cell trait or sickle-cell haemoglobin C disease (Rotter, Luttgens, Peterson, Stock, and Motulsky, 1956; Smith and Conley, 1955).

Vasodilators have been used; Goodman and others (1957) used them to prevent obstructive vascular complications in the last trimester of pregnancy and post partum.

Treatment of the ocular complications when they have occurred is unsatisfactory. Perhaps rest is the most important requirement should a vitreous haemorrhage occur, but prophylactic diathermy to the anastomotic capillary networks also seems to be a useful measure in the prevention of this complication.

\section{Summary}

(1) A further nine cases of ocular complications in sickle-cell haemoglobin $\mathrm{C}$ disease are reported. Seven of these were proven by electrophoresis. In all cases both eyes were involved.

(2) The general characteristics of the disease are outlined.

(3) A specific retinopathy is described. 
(4) Prophylactic measures, which include early recognition by ophthalmoscopy, are indicated in any Negro whose symptoms suggest the presence of the disease.

(5) The serious nature and consequences, from both the general and the ocular standpoints, make this disease one of importance.

We are indebted for the assistance given to us by the Haematology Departments of Guy's Hospital, St. Thomas's Hospital, the Institute of Ophthalmology, and the London School of Hygiene and Tropical Medicine. In particular we are grateful to Prof. Norman Ashton, Dr. Patrick Schofield, Dr. John Agar, Prof. Woodruff, and Dr. Hillsdon Smith for their reports on haematological findings in our cases.

Our thanks are due for permission to examine cases under the care of Mr. H. Stallard, Mr. F. Law, Mr. H. Ridley, Mr. E. S. Perkins, and Mr. C. Cook. The excellent fundus paintings were done by Miss J. Trotman.

\section{REFERENCES}

Aвbott, P. E. (1959). Personal communication.

Bannerman, R. H. O., and White, J. L. (1957). J. Obstet. Gynaec. Brit. Emp., 64, 682.

BAUER, J. (1940). Arch. Surg., 41, 1344.

Bunting, H. (1939). Amer. J. med. Sci., 198, 191.

Chapman, A. Z., Reeder, P. S., Friedman, A. I., and Baker, L. A. (1955). Amer. J. Med., 19, 773.

Charmot, G., and Reynaud, R. (1958). Bull. Soc. Path. exot., 51, 438.

COOK, W. C. (1930). J. Med. (Cincinnati), 11, 541.

DUKE-Elder, S. (1940). "Text-book of Ophthalmology", vol. 3, p. 2648. Kimpton, London.

Diggs, L. W., and Jones, R. S. (1952). Amer. J. clin. Path., 22, 1194.

Edington, G. M., and LEHMANN, H. (1954). Trans. roy. Soc. trop. Med. Hyg., 48, 332. and SARKIES, J. W. R. (1952). Ibid., 46, 59.

Fowler, N. O., Smith, O., and Greenfield, J. C. (1957). Amer. J. med. Sci., 234, 449.

Goodman, G., von SallmanN, L., and Holland, M. G. (1957). A.M.A. Arch. Ophthal., 58, 655.

GrigGs, R. C., and HARRIS, J. W. (1956). Arch. intern. Med., 97, 315.

Harden, A. S. (1937). Amer. J. Dis. Childh., 54, 1045.

HARRIS, H. A. (1929). J. Anat. (Lond.), 64, 1.

Harris, J. W. (1950). Proc. Soc. exp. Biol. (N.Y.), 75, 197.

HanNon, J. F. (1956). Amer. J. Ophthal., 42, 707.

HeNRY, M. D., and ChaPMAN, A. Z. (1954). Ibid., 38, 204.

HerRICK, J. B. (1910). Arch. intern. Med., 6, 517.

Hilkovitz, G. (1957). Brit. med. J., 2, 266.

HOOK, E. W., and COOPER, G. R. (1958). Sth. med.J. (Bgham, Ala.), 51, 610.

Isbey, E. K., Clifford, G. O., and TANAKA, K. R. (1958). Amer. J. Ophthal., 45, 870.

Kimmelstiel, P. (1948). Amer. J. med. Sci., 216, 11.

KenNedy, J. J., and Cope, C. B. (1957). A.M.A. Arch. Ophthal., 58, 163.

Lancet (1957). Leader, 1, 357.

Pauling, L., Itano, H. A., Singer, S. J., and Wells, I. C. (1949). Science, 110, 543.

Phemister, D. B. (1940). Arch. Surg., 41, 1455.

RAPER, A. B. (1950). J. trop. Med. Hyg., 53, 49.

Rotter, R., Luttgens, W. F., Peterson, W. L., Stock, A. E., and Motulsky, A. G. (1956) Ann. intern. Med., 44, 257.

Rudd, C., Evans, P. J., and Peeney, A. L. P. (1953). Brit. J. Ophthal., 37, 353.

ReEse, A. B. (1956). Amer. J. Ophthal., 42, 1.

Smith, E. W., and Conley, C. L. (1954). Bull. Johns Hopk. Hosp., 94, 289.

(1955). Ibid., 96, 35.

and KREVANS, J. R. (1959). Ibid., 104, 17.

Walters, J. H. (1958). Proc. roy. Soc. Med., 51, 646.

Wintrobe, M. M. (1956). "Clinical Haematology", 4th ed. Lea and Febiger, Philadelphia.

Wyman, J., JR, and Allen, D. W. (1951). J. Polymer. Sci., 7, 499. 